\title{
Local Actions to Foster Climate Change Adaptation through Sago Palm Development Initiatives: Examining the Case of South Sulawesi, Indonesia
}

\author{
Marlisa Ayu Trisia ${ }^{1}$, Andi Patiware Metaragakusuma, Katsuya Osozawa, Hu Bai
}

\begin{abstract}
Indonesia has a great potential supply from its local resources, namely sago palm. It could be an alternative crop because its production is not significantly influenced by climate. This paper interrogates local actions in South Sulawesi Province in promoting sago palm. An Analytic Hierarchy Process (AHP), in-depth interview and observation were used for this study. The findings show that sago palm still plays an important role in providing income and food for the local community. However, a drastic change happened due to the expansion of other profitable crops during late 1990s-2000s. Sago production has also decreased significantly by $86.9 \%$ from 2006 to 2013 . Several local actions have been done to revive sago palm, however, these actions were not sustainable due to heavily independent action without support from local government. Now, small initiatives with the local government are being implemented. The local government is endorsing sago palm into Regional Medium-Term Development Plan (RPJMD) 2016-2020 as an alternative crop to adapt to climate change. They are also designing local regulation (PERDA) regarding the protection of sago palm. What is noteworthy is the strong commitment from the government and engaging stakeholders with rural communities wherein these became a key foundation for co-existence of sago palm for a more comprehensive view on sustainable development.
\end{abstract}

Keywords: Climate change adaptation, local action, policy, sago palm, sustainable development

\section{Introduction}

Climate change has become one of the most important issues today especially for Indonesia. Indonesia is the third largest emitters of greenhouse gasses in the world with a total of 3,014 MtCO2e after the United States and China (Sari et al. 2007). Anticipating this, the Government of Indonesia has taken several actions such as developing a National Action Plan (RAN-GRK) in 2011 as a commitment to reduce emission until 26\% in 2020 as business as usual and $41 \%$ with International assistances (Triastuti et al., 2009) and also launched a National Action Plan for Climate Change Adaptation (RAN-API) in 2014 (BAPPENAS, 2013) and Forest and Environment Minister Decree number P.33/Menlhk/Setjen/Kum.1/3/2016 on guidelines for the preparation of climate change adaptation actions. Although Indonesia committed to cope to climate change, the long-term implications of those polices for adaptation are not yet clear.

Adaptation refers the endeavour to adjust through strategies, policies, management, 
technology and stance to minimize the negative impact of climate change, and if possible to utilize and maximize its positive impacts (BAPPENAS, 2013). It also requires the accumulation of skills and assets (Ensor \& Berger, 2009). However, adaptation to climate change is not easy when it is also affecting the agriculture sector and contributes to a decrease in national food production. As the fourth biggest population in the world (Sulaiman, 2010), mostly Indonesia people consume rice as the main staple food. However, the rice production has been influenced by climate change hazards such as flood and drought (Iizumi et al., 2011). An increase of the local temperature by $2{ }^{\circ} \mathrm{C}$ is also projected negatively to rice yields (Porter et al., 2014). Moreover, the rice paddy production has been decreased in Bali by $20 \%$ in the last 20 years because of climate change (Takama et al., 2014). The research projection in 2050 also showed the area of paddy fields will reduce in Java-Bali as well as in Sulawesi, Kalimantan, Sumatra and Lombok (Triastuti et al. 2009). Recent studies have shown that a month's delay in the onset of the wet season due to climate change can decrease rice production by as much as 65\% in West Java and Central Java (Naylor et al., 2007). Therefore, alternative crops more tolerant to variable climate change are necessary in ensuring viable food and human security.

On the other hand, Indonesia has a great potential food supply from its local resources, namely sago palm. Sago palm could be used an alternative crop because its production is not significantly influenced by climate (Bantacut, 2014; Girsang, 2014). It can play an important role in promoting food security because it contains carbohydrates in a higher proportion than rice; 84.7 per $100 \mathrm{mg}$ for sago palm compared to 80.0 per $100 \mathrm{mg}$ for rice (Ministry of Health, 1979). It also produces four times more starch as rice (100-200 kilograms per palm), which is enough to feed a family for one month (Loreto et al., 2004). Sago palm is also excellent for greenbelt vegetation because it acts as an effective sink for carbon sequestration which mitigates climate change (Osozawa, 1998). In addition to being tolerant of tropical acidic soil, preventing soil erosion via a root system which can trap silt, it also has the ability to endure intense isolation, typhoon winds, drought, and prolonged flooding (World Food Programme, 2011). Compared with paddy fields, sago palm is environmental friendly because it conserves soil and water, acts as a buffer zone for flood and sea water intrusion, and has the capability of selfregeneration (Flach, 1983). Due to these advantages, sago palm has been planted in buffer zones as a greenbelt method of rehabilitating degraded lands (Orwa et al., 2009). Adaptation is basically implemented in the local level where climate change occurs with variety of factors such as climatic and geographic condition, house realities, public infrastructure and resources access (Satterthwaite et al., 2007). However, there has been limited study at the local level (Fatorić \& Morén-Alegret, 2013) examining about how different government agencies adapt to climate change specifically related to sago palm development initiatives. There is a huge gap between the acknowledgment and implementation of reducing emissions and adaptation programs in Indonesia, which is often attributed to the failure of the government to supply satisfactory implementation, resources and awareness related to climate change. These assumptions emphasize our claims that this research makes an important contribution to wider literature on local climate change actions and also find effective strategies government to reduce climate change vulnerability. 


\section{Methodology}

This research was conducted during the months of August 2015-April 2016 in 3 regency areas; Luwu Utara, Palopo and Luwu, South Sulawesi Province, Indonesia. The Analytic Hierarchy Process (AHP) were used to define the best strategy in order to support sustainable development and adaptive to climate change in the local area based on RAN-API. This is a mathematically based method that was developed by Saaty (1990) that can be used to express the importance of one element over another. 1 point is given if two elements contribute equally, 3 points is given if judgment favour one element over another, 5 points is given if an element is very strongly favourable, 7 points is given if an element is very strongly dominant, and 9 points is granted if an element is favoured by at least an order of magnitude. Meanwhile, 2,4,6,8 is used to compromise between two judgments. In this study, the Super Decisions tool was used to perform AHP analyses based on local government opinions in 3 regency areas. The first level is composed of the final goal, the second level represents the criteria on the basis of which the national action plan (RAN-API) is to be evaluated and finally the third level presents the element options (Fig. 1). These attributes followed conceptual approach on disaster-resilient components for analytic hierarchy process (Orencio \& Fujii, 2012). The following element options were chosen to fit with the situation in local area formed in the bottom tier (Table 1). The attribute elements for each criterion characterizing climate-resilient communities represented by $\mathrm{C}$ and climate-resilient enabling environments represented by E.

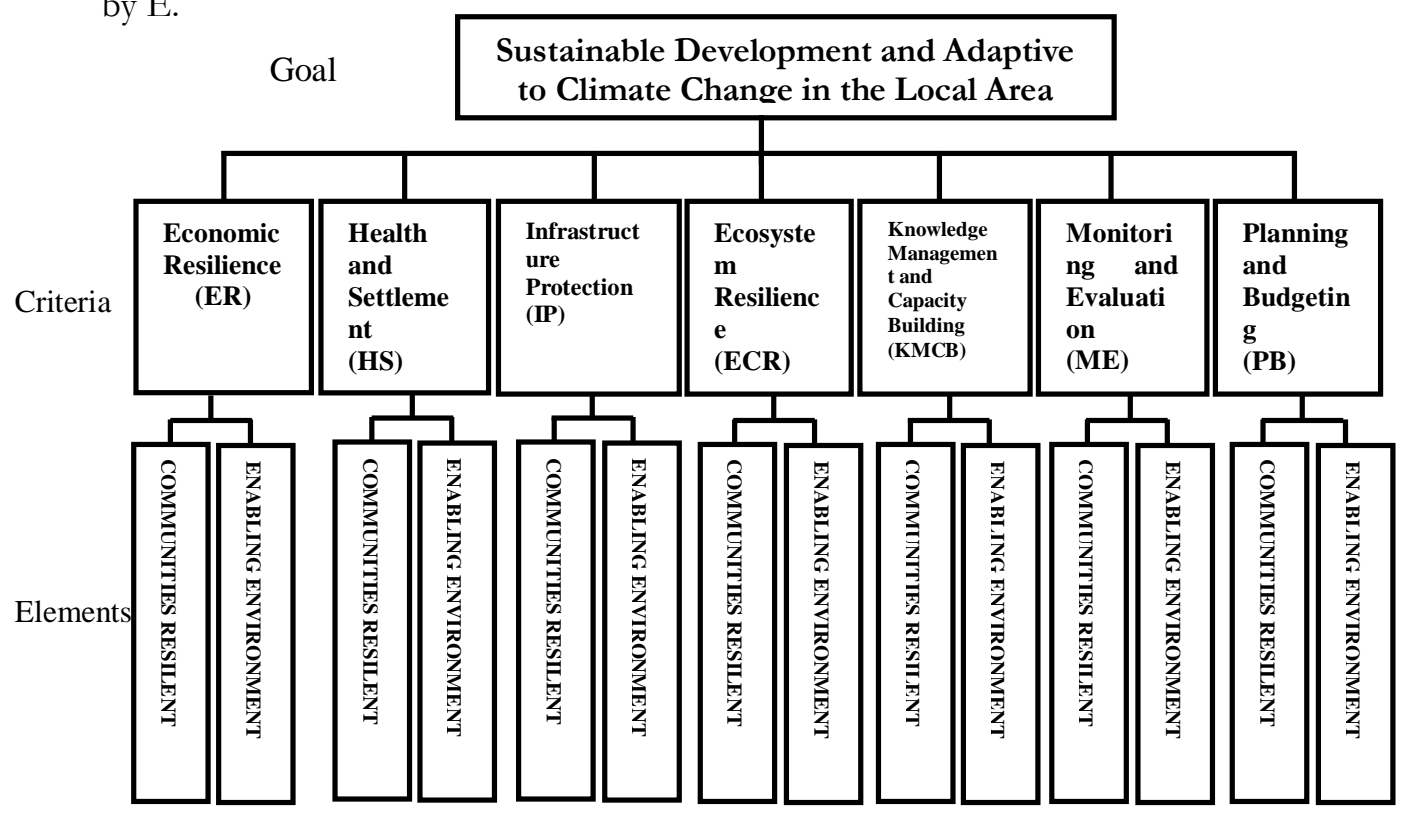

Figure 1. A bierarchical model for sustainable development adaptive to climate change in the local area 
In addition, data was also collected through a review of documented evidence available from the past and current sago palm initiatives. It is then developed into descriptive analysis. Insight were also elicited through in-depth interview and observation to support and cross validate information which all address questions of local climate adaptation and have been inspired by a desire to study and/or foster adaptation as a process of social learning..

Table 1: Components of sustainable adaptive development to climate change in the local area

\begin{tabular}{|c|c|c|c|c|c|}
\hline ER & \multirow{4}{*}{$\begin{array}{l}\text { Criteria } \\
\text { Economic } \\
\text { Resilience }\end{array}$} & \multicolumn{2}{|c|}{$\begin{array}{l}\text { Elements of climate-resilient } \\
\text { communities }\end{array}$} & \multicolumn{2}{|c|}{$\begin{array}{l}\text { Elements of climate-resilient enabling } \\
\text { environment }\end{array}$} \\
\hline ER & & ERC1 & $\begin{array}{l}\text { Expansion of livelihood } \\
\text { system that is more resilient to } \\
\text { climate change }\end{array}$ & ERE1 & $\begin{array}{l}\text { Supportive policy and } \\
\text { institutional structure on } \\
\text { economic resilience }\end{array}$ \\
\hline & & ERC2 & $\begin{array}{l}\text { Development of a climate } \\
\text { information system that } \\
\text { adversely affect local } \\
\text { community }\end{array}$ & ERE2 & $\begin{array}{l}\text { Multi-sector engagement } \\
\text { for managing economy } \\
\text { development }\end{array}$ \\
\hline & & ERC3 & $\begin{array}{l}\text { Development of agriculture } \\
\text { commodity as an alternative } \\
\text { source of food as part of food } \\
\text { security system }\end{array}$ & ERE3 & $\begin{array}{l}\text { Integration of adaptation } \\
\text { efforts to achieve economy } \\
\text { stability }\end{array}$ \\
\hline \multirow[t]{3}{*}{ HS } & \multirow[t]{3}{*}{$\begin{array}{l}\text { Health and } \\
\text { Settlement }\end{array}$} & HSC1 & $\begin{array}{l}\text { Information update on } \\
\text { vulnerability and health risks }\end{array}$ & HSCE1 & $\begin{array}{l}\text { Regulations and legislation } \\
\text { strengthening local level on } \\
\text { the risks of climate change } \\
\text { to public }\end{array}$ \\
\hline & & HSC2 & $\begin{array}{l}\text { Provision of resilient } \\
\text { settlement with strong } \\
\text { structure, good quality and } \\
\text { affordable in the local level }\end{array}$ & HSCE2 & $\begin{array}{l}\text { Climate change resilient } \\
\text { settlement program that } \\
\text { refers to the arising needs } \\
\text { from climate change issue }\end{array}$ \\
\hline & & HSC3 & $\begin{array}{l}\text { Community participation to } \\
\text { maintain settlement }\end{array}$ & & \\
\hline \multirow[t]{2}{*}{ IP } & \multirow[t]{2}{*}{$\begin{array}{l}\text { Infrastruct } \\
\text { ure } \\
\text { Protection }\end{array}$} & IPC1 & $\begin{array}{l}\text { Identification infrastructure } \\
\text { condition and vital facilities in } \\
\text { the local area }\end{array}$ & IPE1 & $\begin{array}{l}\text { Accomplished vulnerability } \\
\text { assessment for all } \\
\text { infrastructure }\end{array}$ \\
\hline & & IPC2 & $\begin{array}{l}\text { Adoption of climate-resilient } \\
\text { infrastructure }\end{array}$ & IPE2 & $\begin{array}{l}\text { Integrated infrastructure } \\
\text { layout management with } \\
\text { spatial planning }\end{array}$ \\
\hline \multirow[t]{3}{*}{ ECR } & \multirow[t]{3}{*}{$\begin{array}{l}\text { Ecosystem } \\
\text { Resilience }\end{array}$} & $\begin{array}{l}\text { ECRC } \\
1\end{array}$ & $\begin{array}{l}\text { Identification ecosystem } \\
\text { condition in the local area }\end{array}$ & ECRE1 & $\begin{array}{l}\text { Legal systems to respond } \\
\text { utilization of natural } \\
\text { resources in an integrated } \\
\text { manner }\end{array}$ \\
\hline & & $\begin{array}{l}\text { ECRC } \\
2\end{array}$ & $\begin{array}{l}\text { Maintenance and rehabilitation } \\
\text { of degraded ecosystem }\end{array}$ & ECRE2 & $\begin{array}{l}\text { Bilateral and multilateral } \\
\text { support on issues related } \\
\text { threat to ecosystem }\end{array}$ \\
\hline & & $\begin{array}{l}\text { ECRC } \\
3\end{array}$ & $\begin{array}{l}\text { Cooperation with community } \\
\text { to support environmental } \\
\text { practices }\end{array}$ & ECRE3 & $\begin{array}{l}\text { Macro plan improvement } \\
\text { on integrated ecosystem as } \\
\text { adjusted to spatial planning }\end{array}$ \\
\hline $\begin{array}{l}\text { KMC } \\
\text { B }\end{array}$ & $\begin{array}{l}\text { Knowledg } \\
\mathrm{e} \\
\text { Manageme } \\
\text { nt and } \\
\text { Capacity }\end{array}$ & $\begin{array}{l}\mathrm{KMC} \\
\mathrm{BC} 1\end{array}$ & $\begin{array}{l}\text { Capacity enhancement of } \\
\text { community and knowledge } \\
\text { management related to the } \\
\text { threats of climate change } \\
\text { through socialization and }\end{array}$ & $\begin{array}{l}\mathrm{KMCBE} \\
1\end{array}$ & $\begin{array}{l}\text { Development of climate } \\
\text { information and } \\
\text { communication supporting } \\
\text { system }\end{array}$ \\
\hline
\end{tabular}


Building public awareness

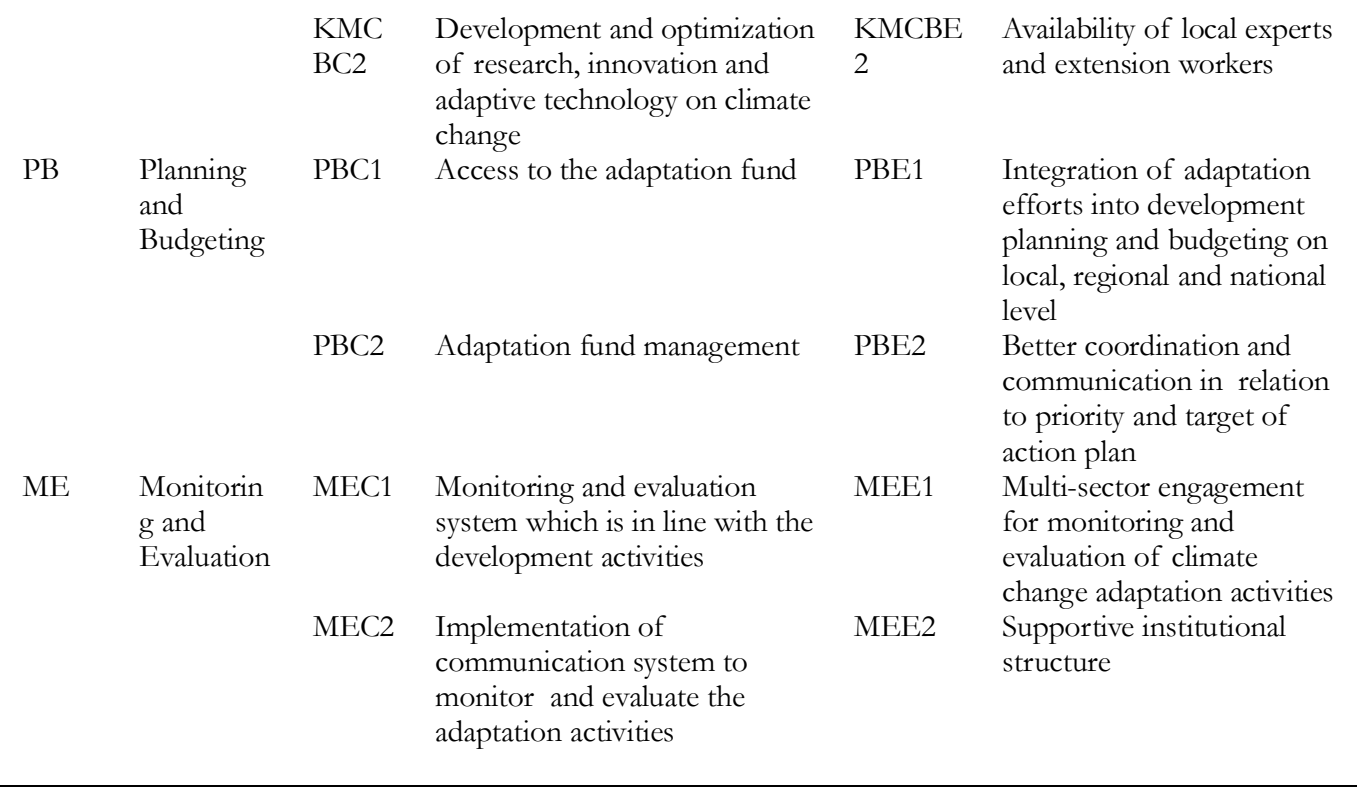

\section{Result and discussion}

\subsection{Current Status of Sago Palm: national vs local level}

Sago has been recognized as one of the oldest plants consumed by human beings (Ave, 1977). It is a native Indonesian plant covering a total area around 107.906 hectares with a total production of 155.061 tons (Directorate General of Crops, 2015). However, the national production is only $10 \%$, far below the national sago cultivation potential of 1.128 million hectares (Pietries, 1996). Based on Directorate General of Crops, the exportation of sago in 2013 only earned 1.96 million US dollars. This is far below from other crops such as palm oil (17.67 billion US dollars), rubber (6.90 billion US dollars), coffee (1.17 billion US dollars) and cacao (1.51 billion US dollars). Furthermore, only $0.05 \%$ from the total state budget (ABPN) during 2012-2014 is allocated to the sago palm national program, thus considered relative small as compared to other annual crops. Despite the recognition of sago palm as a valuable resource for food and industry as early in the 1970s, the development remains flat (Regional Research and Development Agency, 2008). In addition, at the national level, there is no comprehensive strategy to include, develop or promote sago palm in their long-term action plans in addressing the needs of the country's supporting economic and food security in the face of climate change. However, more than 45 sago-based food products are found in 21 of 33 provinces in Indonesia (Food Security Agency, 2012) which prove that sago has a much wider utilization and great potential to be developed at the local level with a local-based approach.

South Sulawesi is one of the sago producers in Indonesia. The three major areas of sago 
palm cultivation in this region are Luwu Utara District, Palopo City and Luwu District. According to the data of Department of Plantation of South Sulawesi, sago production in those 3 areas had decreased significantly by $86.9 \%$ from 2006 to 2013. It is recorded that total sago production in 2006 was $14,442.47$ tons but recently, the production in 2013 was only $1,896.20$ tons. The significant decrease thru the years is because of the following:(a) absence of rejuvenation/re-planting of sago palm, (b) the expansion of other profitable crops such during late 1990-2000s and (c) lack of support from the local government. Despite under these conditions, Sago palm is still considered an important role in providing income and food for the local community.

Although there is an observed decline of sago production, the consumption of sago products is recently increasing in South Sulawesi. One example is the case study of dried refining sago producer in Palopo city which showed $557.14 \mathrm{~kg}$ crude sago is needed every month to produce approximately $390 \mathrm{~kg}$ dried refining sago, thus a total profit amount of IDR 3.6 million (264.7 US dollars). According to Metaragakusuma (2014), both the production of refining sago and profit in sago consumption may increase in the future due to the popularity of sago food processing (kapurung). The number of commercial kapurung restaurants has increased with an average growth of $28.7 \%$ during the last 14 years (Genda 2012; Metaragakusuma 2014). Mass media such as newspaper, magazine and social media was an important factor that made kapurung popular recently. It changed the sago image from a food type of the poor into a healthy and interesting food sustenance. This popularity was intensified further due to the "back to nature" movement wherein many are now very particular to the type of food they eat. The local government has also supported the inclusion of kapurung as a main menu for government events as well as the main product for exhibition. Furthermore, in Luwu Utara regency, they patented kapurung since 2014 and currently expanding and developing it into a food industry. Indeed, these activities undermine the sago culture at the local area, which has been inherited from their ancestors and survived in our current society. The local government has started already supporting sago development, yet, its continuity is still quite questionable. Therefore, more attention must be given because the function of sago palm culture is not only limited towards its social and economic values but it can be developed as an alternative solution for climate change adaptation at the local level.

\subsection{Priority criteria and elements for sustainable adaptive development to climate change in the local area}

Luwu, Palopo, and Luwu Utara are likely to be affected more by climate variability than other areas. Based on Climate Vulnerability and Capacity Analysis Report in South Sulawesi by CARE, it showed the climatic hazards that impact the communities are flooding, drought and extreme weather. According to the vulnerability to climate hazards index (Composite Climate Hazards Index / CCHI), Luwu Utara is categorized as "Very High" for the projected 2020 and subsequently in 2050, it is deemed as "Very High and vulnerable" to climate hazards (DNPI, 2011). Based on SIDIK (Inventory System and Vulnerability Index) of the Ministry of Forestry, Luwu scored an exposuresensitivity index of 0.925 , while the adaptability index is 0.499 which put this regency 
into very high vulnerability to climate change. Moreover, Palopo and Luwu are placed in the high vulnerability coping range with a total score of 0.775 and 0.645 , respectively, for exposure-sensitivity index while 0.637 and 0.704 for the adaptability index, respectively. These findings are also confirmed by the National Board for Disaster Management which reported that Luwu, Palopo and Luwu Utara are prone to flooding and drought. Therefore, adaptive actions are needed in order to prevent the worse impact from climate change.

The Analytic Hierarchy Process (AHP) was used to express priority action for supporting a sustainable development and adaptive to climate change in the local area. The result of priority vector, maximum eigenvalue $(\lambda \max )$ and inconsistency ratio (IR) for each criteria are shown in the Table 3. Based on the weights of the criteria at this level, Knowledge Management and Capacity Building (KMCB) was ranked as the highest followed by Economic Resilience (ER) and Ecosystem Resilience (ECR). These three criteria accounted for $70.37 \%$ of the overall weights being compared. In contrast, the lowest criteria were Monitoring and Evaluation (ME), Planning and Budgeting (PB), Infrastructure Protection (IP) and Health and Settlement (HS). The $\lambda \max$ was 7.738 and the IR value was 0.093 which satisfy the 0.10 threshold.

Table 3: Ranking of various criteria of sustainable adaptive development to climate change in the local area

\begin{tabular}{|c|c|c|c|}
\hline Rank & Criteria & Weight & \\
\hline 1 & KMCB & 0.327 & \multirow{3}{*}{$\lambda_{\text {max }}=7.738$} \\
\hline 2 & ER & 0.218 & \\
\hline 3 & ECR & 0.158 & \\
\hline 4 & HS & 0.115 & $\mathrm{I}_{\mathrm{R}}=0.093$ \\
\hline 5 & IP & 0.084 & \\
\hline 6 & PB & 0.056 & \\
\hline 7 & ME & 0.041 & \\
\hline
\end{tabular}

KMCB criterion was deemed the most important for describing sustainable development and adaptive to climate change in the local area. Knowledge is defined as a set of understandings, capacity for imagining and perceiving (Gumucio et al., 2011). It is embedded as part of institutional capacity and knowledge, as well as for policy-making processes in relation to climate change adaptation, play a significant role in sustainable development climate change. Without knowledge, the policy cannot be perfectly implemented at the local level. Based on Table 4, the priority element that characterized climate-resilient communities of KMBC was the "capacity enhancement of community and knowledge management related to the threats of climate change through socialization and public awareness" (KMCBC1). It accounted for $75 \%$ of the overall alternatives. In addition, the priority of climate-resilient enabling environment was determined to be "the availability of local experts and extension workers" (KMCBE2). Indeed, public awareness is needed to understand how climate change will affect their area. Moreover, the availability of local experts and extension workers may support 
communities through process that begins with creating an understanding of current vulnerabilities and their strategies to respond to climate changes.

Indonesia has a strong reliance to their natural resources, thus ER is needed in order to overcome the consequences of climate change and variability. This criterion also represents the needs of local stakeholders to reach a good and workable system that ensures grounded economy on how the hazards of climate change affect their lives. This happens because communities understand how fragile their livelihood systems can cause a mountable level of hazard relating to its vulnerability (Orencio \& Fujii, 2013). For ER, the two important elements which characterize climate-resilient communities were "expansion of livelihood system that are more resilient to climate change" (ERC1) and "expansion of commodity as an alternative source of food as part of food security system" (ERC3), whereas the two priorities for elements of climate-resilient enabling environment were "supportive policy and institutional structure on economic resilience" (ERE1) and "multi-sector engagement for managing economy development" (ERE2), with $I_{R}$ values falling within 0.006 and 0.037 respectively. Ensor \& Berger (2009) mentioned that the economic resilience requires the accumulation of skills as well as assets. It also includes the ability to innovate and the capacity to learn (Peterson, 2000). Moreover, positive correlations have been found with education level, experiences of past conditions and social customs (De Wit, 2006; Leith \& Haward, 2010) which evolve different livelihood strategies that may be necessary in responding to climate change.

The vulnerability of communities due to climate change is not only limited by place or location (Laukkonen et al., 2009) but also environmental interaction and social condition that determine exposures and sensitivities (Fatorić \& Morén-Alegret, 2013). Therefore, the recognition of ECR as an essential criterion can be attributed to the sustainable adaptive system. The two most importance elements of ECR for climate-resilient communities were "cooperation with community to support environmental practices" (ECRC3) and "identification ecosystem condition in the local area" (ECRC1), whereas the two priorities for elements of climate-resilient enabling environment were "legal systems to respond utilization of natural resources in an integrated manner" (ECRE1) and "macro plan improvement on integrated ecosystem as adjusted to spatial planning" (ECRE3). This result demonstrated the recognition of local government to involve community including identify ecosystem condition in the local area for better environmental practices. Consequently, more sufficient decision making communication, information transparency and social trust are required. Furthermore, legal systems and improving of macro plan to spatial planning are important but the poor implementation is detrimental for sustainable development. For example, the lack of commentary on the impact and effective implementation of forest and land conversion laws in Indonesia caused rapid deforestation which produced GHG emission which amounted to 57\% from its total that contributed to global warming and climate change escalation (Page et al., 2002). Hence, actions aimed at protecting ecological resilience that consider the social and economic systems will usually be more sustainable and effective in the long-term (McCook et al., 2007). 
Table 4: Ranking of various alternatives of sustainable development adaptive to climate change in the local area

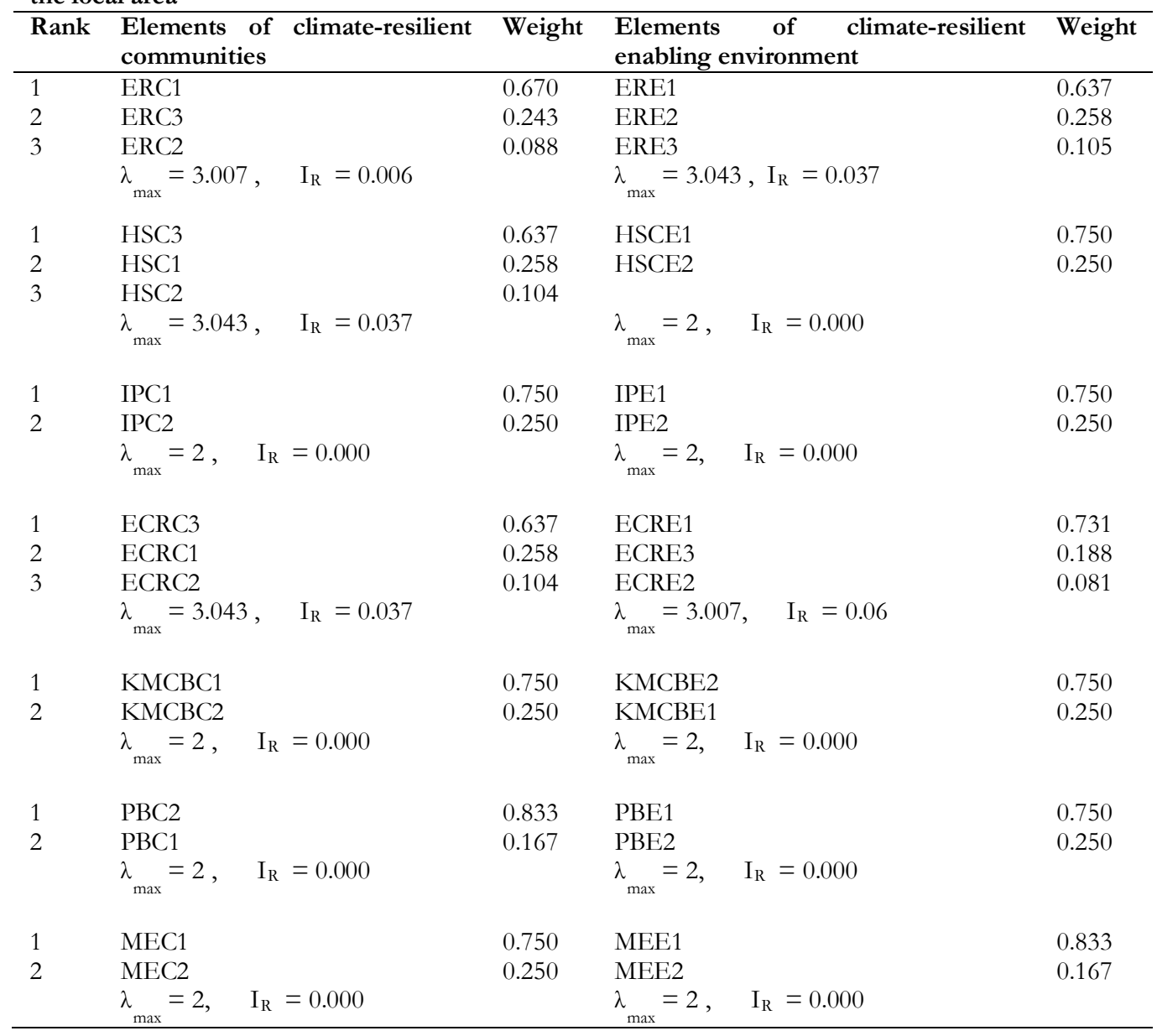

\subsection{Sago palm development Initiatives for climate change adaptation}

The absence of rejuvenation/ re-planting of sago palm and the expansion of other profitable crops led to a decline in sago production. Therefore, small local actions have been done to revive sago palm through "Gerakan Ayo Tanam Sagu" or "Let's Plant Sago" and sago palm community service program (KKN) by university. "Gerakan Ayo Tanam Sagu" or "Let`s Plant Sago" started in 2010 by Mr. Askar M. Landa. He started this movement by planting 100 sago in 1 hectare, mixed with Jabon tree (Anthocephalus cadamba) in Pengkajoang Village, Luwu Utara. His vision is to prevent the extinction of sago and inspire people to plant sago. Sago area is categorized as sago palm forest which is growing uncultivated without any external technology inputs, so, planting sago is unusual for the local community. The growth of sago palm is also very slow (8-10 years) so local people thought it is better to plant another crop or to use the land for more profitable sector. However, Mr. Askar is very persistent in promoting the 
sago movement. In 2012, He started to use a popular social media platform, Facebook, to promote sago by the name of "Gerakan Ayo Menanam". The campaign of the importance of sago forest for the environment and preserving sago culture has been conducted with bigger goal which is establishing "Sago Village". Aligned with that activity, in September 2012, an international collaboration program between the students of Ehime University and Hasanuddin University was carried out through sago palm community service program $(\mathrm{KKN})$ in Luwu Utara. 2 hectares of land were planted with 200 trees of sago by both universities together with local community and senior high school students in this village. The funding of this project was from NPO Heiwa Kankyou Moyai Network. They provided the seeds to be planted in this project. It was expected that the project would provide a good impact in the succession of the sago culture in South Sulawesi. However, those actions were not sustainable and had short impression due to heavily independent action without support from the local government.

Responses to climate change require not only local knowledge but also the translation of information into a learning process (Laukkonen et al., 2009). It demands the inclusion from all social scales and the recognition by the local government as a policy maker. The Institutional Analysis and Development (IAD) framework adjusted for adaptation governance analysis by Bisaro \& Hinkel (2016) mentioned that the adaptation action is characterized by biophysical conditions, community attributes and institutions (Fig. 2). Based on this premise, the small sago palm development initiatives along with the local government are implemented through Sago Palm Restoration Project by Ehime University from 2015 to 2018, a project granted by the Ministry of Education, Culture, Sport, Science and Technology with total amount of 14.3 million Yen (126,400 US Dollar). Its main target is to protect and rehabilitate sago palm, while at same time meeting the socio-economic development for sustainable management of ecosystem. The approach was adjusted into a strategic collaboration with the local government. This initially departed from a predefined expert view that sago palm could be delineated and understood solely through the use of economic and ecological service and how it was meaningful to them. The project expanded its partnership and coordination among different government agencies, local university, NGO, private company and its community.

After several meetings and discussion, the project is evolving and the government is becoming more immersed in the realities of local potency which emphasized to a shift of boarder concerns of sago palm development as an alternative to adapt to climate change. As Purnomo et al (2005) stated that each location has different types of collaboration with different arrangements among stakeholders. Consequently, the strategies can be designed and implemented according to the livelihood objectivities and local situation. For example in Luwu Utara, the approach is more emphasis on sago as a main symbol/identity which is a symbol of harmony, solidness, and rigidity. For Palopo and Luwu, the strategies are more into preserving kapurung as the traditional food from Luwu and source of economy for the community. 


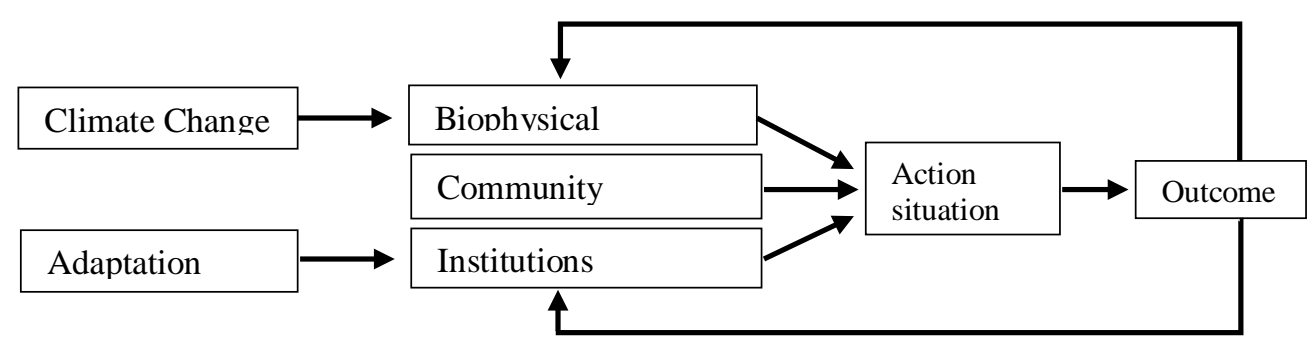

Figure 2. IAD framework adjusted for adaptation governance analysis (Bisaro \& Hinkel, 2016)

Sago Palm Restoration Project is an ongoing project, thus far, the positive results of this project are shown through the willingness of local government to endorse sago palm into the Luwu Utara Regional Medium-Term Development Plan (RPJMD) 2016-2020 as an alternative crop to adapt to climate change and providing land area to plant sago palm. Aligned with this project, the Legislative council (DPRD) with support from FP2KEL (Forum Pemuda Pemantau Kinerja Eksekutif dan Legislatif/Youth Forum for Executive and Legislative Performance Monitoring) is designing local regulation (PERDA) regarding the protection of sago palm. This regulation is expected to protect sago for future generation. Furthermore, local government in Palopo have launched sago seminar national and sago festival in 2012 to increase the level awareness within government. They also proposed the establishing of Sago Study Center/ Sago Techno Park to Ministry of Education, which engage local universities in South Sulawesi.

In Indonesia, the new policy on decentralization created the legal frame conditions for people's participation in the management of natural resources (McCarthy, 2000). However, it also require how effective and capable each involved local government in supporting their communities (Laukkonen et al, 2009) because of their wide range of activities in resources, community development, economic growth, and natural resources management (Pini et al, 2007). Legal instrument is also important to improve the implementation systems and the capacity of key actors for sustainability of the project. So far, policy development from central to local level has been implemented through RAN-API, which assist local government to provide better legal instrument but at present there is no special institution in those 3 areas which can estimate the possible impact of climate change and therefore no specific policies that support climate resilient livelihoods, yet. However, the enthusiasm of local government to support sago palm for sustainable and climate friendly development can be one of the positive progresses. An improved natural resources management with holistic approach is required for development including better understanding for culture and social issues before changes can be introduced.

\section{Conclusion}

An appreciation of local tradition such as sago culture as part of climate change adaptation is still an unfamiliar approach for Indonesia. It needs a strong commitment and synergy between national and local government. Furthermore, improving access to climate-related information and awareness raising will be the most important support to any development and adaptation strategy. Considering, a lot of resources are allocated 
for emergency and reconstruction activities which need more support rather than prevention and preparation activities, conserving sago as part of climate change adaptation can be a cheaper option because it is part of community life. The aspect of a strong commitment from government as well as stakeholder engagement with rural communities is the key foundation for co-existence of sago palm for a more comprehensive view on sustainable development.

\section{References}

Avé, J. (1977). Sago in insular South-East Asia: Historical aspects and contemporary use. Paper presented at The First International Sago Symposium 1976 (pp. 21-30). Kuching-Malaysia: Kemajuan Kanji.

Bantacut, Tajuddin. (2014) Indonesian Staple Food Adaptations for Sustainability in Continuously Changing Climates. Journal of Environment and Earth Science, 4(21), 202-16.

BAPPENAS. (2013). National Action Plan for Climate Change Adaptation (RAN-API), Synthesis Report. BAPPENAS: Jakarta.

Bisaro, Alexander \& Hinkel, Jochen. (2016). From Governance of social dilemmas in climate change adaptation. Nature Climate Change, 6, 354-359.

De Wit, M. (2006). Climate change and African agriculture: how farmers perceive and adapt to climate change. Africa: Centre for Environmental Economics and Policy.

Directorate of Perennial Crops. (2015). Tree Crop Estate Statistic of Indonesia 2013-2015. Jakarta; Ministry of Agriculture.

DNPI. (2011). Vulnerability mapping, inventory of policies and institutions in the provinces in order to prevent the impact of climate change. Jakarta: DNPI.

Ensor, J and Berger, E. (2009). Understanding climate change adaptation,lesson learn from community-based approaches. United Kingdom: Practical Action Publishing.

Fatorić, S and Morén-Alegret, R. (2013). Integrating local knowledge and perception for assessing vulnerability to climate change in economically dynamic coastal areas: The case of natural protected area Aiguamolls de l’Empordà, Spain. Ocean Coastal Management, 85, 90-102.

Flach, M. (1983). The Sago Palm : Domestication, Exploitation and Products. Rome, Italy: FAO.

Food Security Agency. (2012). Roadmap of Food Diversification 2011-2015. Jakarta: Ministry of Agriculture.

Genda, N. (2014). The utilization and future possibility of sago palm in Indonesia (Unplublished master`s thesis). Ehime University

Girsang, Wardis. (2014). Socio-Economic Factors That Have influenced the Decline of Sago Consumption in Small Islands: A Case in Rural Maluku, Indonesia. South Pacific Study, 34(2): 99-116.

Gumucio, S., Merica, M., Luhmann, N., Fauvel, G., Zompi, S., Ronsse, A., Courcaud, A., Bouchon, M., Trehin, C., Schapman, S. (2011). Data Collection Quantitative Methodes, the KAP Survey Model (Knowledge, Attitude, Practices). Retrieved from https://issuu.com/medecinsdumonde/docs/47-the-kap-survey-model-knowledge-a.

Iizumi, Toshichika, Masayuki Yokozawa, and Motoki Nishimori. (2011). Probabilistic Evaluation of Climate Change Impacts on Paddy Rice Productivity in Japan. Climatic Change, 107(3-4): 391-415.

Laukkonen, L., Blanco, P., Lenhart, J., Keiner, M., Cavric, B., Kinuthia-Njenga, C. (2009). Combining Climate Change Adaptation and Mitigation Measures at the Local Level. Habitat International. 287292.

Leith, P \& Haward, M. (2010). Climate change adapatation in the Australian edible oyster industry: an analysis of policy and practice. Australia: University of Tasmania.

Loreto, A.B., Quevedo, M.A., Mariscal, A. M., Okazaki, Masanori. 2004. Development of a village-level sago starch grater machine. In: Regional Research and Development Symposium. Philippines.

McCarthy, J. F. (2000). The Changing Regime: Forest Property and Reformation in Indonesia. Development and Change, 31, 91-129.

McCook L. J., Marshall, P. C., Folke, T., Hughes, M., Nyström, Obura, D., Salm, R. (2007). Ecological Resilience, Climate change and the Great Barrier Reef. Retrieved from http://www.gbrmpa.gov.au/ data/assets/pdf file/0017/4445/chpt-4-McCook-et-al-2007.pdf 
Metaragakusuma, A.P. (2014). Sago development in South Sulawes: its current situation, new movement and the succesion of the sago culture by small scale farmers (Unplublished master`s thesis). Ehime University.

Naylor, R.L., Battisti D.S. Vimont, W.P. Falcon, and M.B Burke. (2007). Assessing Risks of Climate Variability and Climate Change for Indonesian Rice Agriculture. Proceeding of the National Academic of Science, 114, 7752-57.

Orencio, P. M., \& Fujii, M. (2012). A localized disaster-resilience index to assess coastal communities based on an analytic hierarchy process (AHP). International Journal of Disaster Risk Reduction, 3 (2013) 6275 .

Orwa, C., Mutua, A., Kindt, R., Jamnadass, R., Anthony, S. (2009). Agroforestree Database: A Tree Reference and Selection Guide. Kenya.

Osozawa, K. (1998). Sago farmers in eastern part of Indonesia and relaxation of regulation in Japan. Asano Naonobu kashiyo (Ed.). Japan: Japanese Agriculture and Forestry and relaxation of regulation.

Peterson, G. 2000. Political Ecology and Ecological Resilience: An Integration of Human and Ecological Dynamics. Ecological Economics, 35, 323-336.

Purnomo, H., Mendoza, G. A., Prabhu, R., Yasmi, Y. (2005) Developing multi-stakeholder forest management scenarios: a multi-agent system simulation approach applied in Indonesia. Forest Policy and Economics, 7, 475-491.

Pietries, D. (1996). The Study About Sago Forest in Maluku. Bandung: Bogor Agricultural University.

Pini, B., Wild River, S., McKenzie, F. M. H. (2007). Factors Inhibiting Local Government Engagement in Environmental Sustainability: Case Studies From Rural Australia. Australian Geographer, (38)2, 161-175.

Porter, J.R., Xie, L., Challinor, A., Cochrane, K., Howden, S., Iqbal, M., Lobell, D., Travasso, M. (2014). Food Security and Food Production Systems. Cambridge: Cambridge University Press.

Regional Research and Development Agency. (2008). Sago Commodity Development as an Alternative Food in South Sulawesi. South Sulawesi: Department of Agriculture in South Sulawesi.

Saaty, T.L. (1990). How to make a decision: The Analytic Hierarchy Process. European Journal of Operational Research, 47(3), 9-26.

Sari, A., Maulidya, M., Butarbutar, R., Sari, R., Rusmantoro, W. (2007). Executive Summary: Indonesia and Climate Change, Working Paper on Current Status and Policies. Jakarta: PEACE.

Satterthwaite, D., Huq, S., Pelling, M., Reid, H., Lankao, R. (2007). Adaptation to Climate Change in Urban Areas: The Possibilities and Constraints in Low and Middle Income Nations. London.

Sulaiman, D. S. (2010). Lesson Learned from 2010 Indonesia Population and Housing Census. Retrieved from http://www.stat.go.jp/english/info/meetings/eastasia/pdf/13pa2idn.pdf

Takama, Takeshi, Pudji Setyani, and Edvin Aldrian. (2014). Climate Change Vulnerability to Rice Paddy Production in Bali, Indonesia. In Handbook of Climate Change Adaptation. Berlin: Springer.

Triastuti, U., Tedjakusuma, E., Sriyanti, Girianna, M., Darajati, W., Hernowo, B., Hidayat, Y., Prihartono, B., Simarmata, M., Azdan, M., Armawikarta, A., Hidayat, B., Mintzer, Irving. (2009). Indonesia Climate Change Sectoral Roadmap ICCSR Synthesis Report. BAPPENAS: Jakarta.

World Food Programme. (2011). Climate Change Adaptation (CCA): A Critical Time for Action. Retrieved from https://www.humanitarianresponse.info/system/files/documents/files/Final $\% 20 \mathrm{WFP} \% 20 \mathrm{DPR}$ \%20Programme $\% 20-\% 20$ CCA.PDF 